\title{
The Role of Parents in Developing Naturalistic Intelligence in Early Childhood
}

\author{
Faizatul Faridy ${ }^{1, *}$ Aulia Rohendi ${ }^{1}$
}

\author{
${ }^{1}$ Universitas Islam Negeri Ar-Raniry, Banda Aceh, Indonesia \\ ${ }^{*}$ Corresponding author. Email: faizatul.faridy@ar-raniry.ac.id
}

\begin{abstract}
Population growth and economic development have the potential to increase damage on earth over time. A large number of falling trees and changes in land use for development, the increase in millions of tons of waste, the increase in industry and vehicles also contribute to the threat to the environment. The above problems are not easy to overcome in the near future; it needs a long process and expensive costs. One solution that can be done by every individual is to love the environment and understand the relationship between humans and the environment, that human behavior will have an impact on the environment which will later return to its own effect on humans. Cultivating a love for the environment can be done from an early age, namely by developing intelligence called naturalistic intelligence. This research was conducted to analyze the role of parents in developing naturalistic intelligence in early childhood. This study uses a qualitative approach with a case study design. Data collection was carried out using observation sheets, indepth interviews and documentation. The findings of this study reveal that only $42 \%$ of parents are developing their children's naturalistic intelligence at home. It was also found that parents who develop their children's naturalistic intelligence love the environment so much that they want their children to love and protect the environment.
\end{abstract}

Keywords: Naturalistic intelligence, parents' role, environment

\section{INTRODUCTION}

Deforestation is the hottest news in 2019. Some forest areas in Indonesia experienced severe fires which caused haze in some areas. The same thing happened on Amazon, where many people attributed this forest fire to deforestation. Burning the forest does not only harm humans but also animals. In addition to fires and tree cutting, the use of plastic in the world is also increasing. Plastic wastes not only threaten the lives of animals but also damage the ecosystem. Ariwidodo (2014) revealed that there is a relationship between knowledge of the environment and their participation in environmental conservation. This means that by studying the natural surroundings, humans will protect the environment more than those who do not learn it. Recognizing and studying the environment does not always have to be at school. It could be done through habituation at home by parents even through simple things that are often encountered by children in their surroundings.

There are several previous studies conducted on naturalistic intelligence in early childhood, including research conducted by Juniarti (2015) saying that naturalistic intelligence can be improved through field visit methods. Furthermore, research conducted by Rocmah (2016) states that naturalistic intelligence can be improved through messy play games. There are many other studies that examine the game that can improve naturalistic intelligence, but the authors have not found a specific study looking at the role of parents in developing children's naturalistic intelligence at home. So the authors are interested in seeing further how the role of parents in developing children's naturalistic intelligence and how their understanding of naturalistic intelligence.

\section{LITERATURE REVIEW}

\subsection{Naturalistic Intelligence}

Naturalistic Intelligence is one's ability to relate and adapt to nature (Wijanarko, 2012). According to Gardner (Sujiono, 2011) naturalistic intelligence is the ability to recognize and categorize species both flora and fauna in the surrounding environment, recognize the existence of species, and map relationships between species. This intelligence also includes sensitivity to other natural phenomena (for example cloud formations and mountains). Widayati (Suyadi, 2010) added that naturalistic intelligence is the ability to recognize various types of flora (plants), fauna (animals), and other natural phenomena, such as animal origin, plant growth, solar system, various galaxies, etc. So, according to Prasetyo and Andriani (2009) naturalistic intelligence is the capacity to recognize and classify certain features in the surrounding physical environment, such as animals, plants, and weather conditions. According to Armstrong (2013) 
naturalistic intelligence involves the ability to recognize natural forms around us: flowers, trees, animals, fauna and other flora. It also includes sensitivity to other forms of nature such as cloud composition and geological features of the earth. From some of the above opinions, it can be concluded that naturalistic intelligence is the child's interest in the environment both for flora and fauna. The naturalistic intelligence in children can be developed by doing activities in the wild like observing plants and living things or through habituation at home.

\subsection{Indicators of Naturalistic Intelligence}

Gunawan (2012) mentions that there are several indicators of naturalistic intelligence, including:

1) Children explore the natural environment and the human environment with full interest and enthusiasm.

2) Children like to observe, recognize, interact, or care about objects, plants, or animals.

3) The child is able to classify objects according to the characteristics of the object.

4) Children like to use equipment such as microscopes, binoculars, telescopes, and computers to study an organism or system.

5) Children enjoy learning the life cycle of flora and fauna.

\section{Table 1 Data of participants}

6) Children learn the taxonomy of plants and animals.

7) Children interested in a career in biology, ecology, chemistry, and botany.

8) Children love caring for plants or animals According to the generation type of assumptions, we divided the existed work into two categories.

\section{METHOD}

The research uses qualitative method using a case study design that focuses on one particular object. The data can be obtained from various sources (Nawawi, 2003), and in this study, the data collection was carried out using observation sheets, in-depth interviews, and documentation. The research was conducted in Banda Aceh, the capital city of Aceh Province, and also Aceh Besar, a regency in Aceh Province, Indonesia. The participants are randomly selected using the snowball technique. In this study, the authors chose participants from diverse family backgrounds in the hope of finding varied information. The selected participants are from 7 families (Table 1), and the mothers represented the parents for the in-depth interviews.

\begin{tabular}{|l|l|l|l|l|l|}
\hline No. & Participants & Occupation & Residence & Child's Name & Age of Child \\
\hline 1 & BC & Entrepreneur & Geuceu & MK & 7 th \\
\hline 2 & NA & Lecturer & Lamlhom & MI & 7 th \\
\hline 3 & RF & Housewife & Batoh & KN & 6 th \\
\hline 4 & RM & Housewife & Penyerat & AN & 5 th \\
\hline 5 & RU & Teacher & Sp. Rima & DN & 8 th \\
\hline 6 & ZDM & Lecturer & Lamgugob & GLS & 8 th \\
\hline 7 & KH & Entrepreneur & Ajun Jeumpet & MK & 6 th \\
\hline
\end{tabular}

\section{FINDINGS AND DISCUSSION}

Based on the results of interviews and observations with several families obtained information as follows. First, most parents claim to have never heard of naturalistic intelligence, interview results show that only 2 out of 7 parents have heard of naturalistic intelligence and that too does not know clearly how naturalistic intelligence is.

Second, loving the environment is passed on to children through habituation. This is done by parents involving children when gardening at home, caring for pets and some are simply bringing children to an outdoor playground with the intention that children are interested in nature. As revealed by $\mathrm{BC}$ during the interview, "Introducing the environment, which includes plants, animals, mountains, sea, and its contents, and the surrounding conditions, for example, by inviting him to plant flowers, take care of them, feed the pets, take care of the pets (there have been turtles, cats, fish but now all that remains are the rabbits) and everything is taught completely with the (acknowledgments of) risks. For example, we have to plant trees so that our house is cool, not hot, there are squirrels and birds can sleep there, and there are fruits if we want to eat, etc..." (Fig.1). 


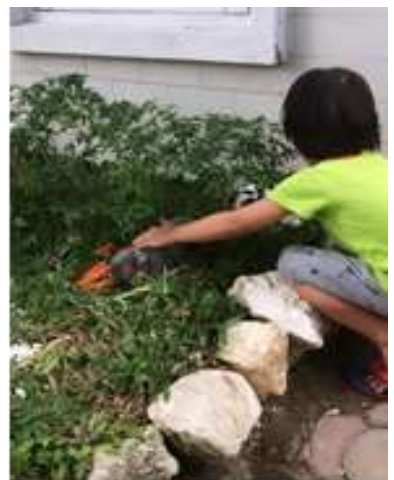

Figure 1 BC's son, MK, taking care of his pet

In contrast to $\mathrm{BC}, \mathrm{RF}$ revealed that she and her husband do not directly teach naturalistic intelligence, but in some circumstances, she often teaches $\mathrm{KN}$ to love animals. RF stated that "There is no special time, if suddenly there is a cat eating, I teach $\mathrm{KN}$ to share food with cat. But we haven't taught about the plants." (Fig.2.) Similar to RF, RM revealed that she does not specifically teach naturalistic intelligence, as the results of the interview "Usually if there is an opportunity or an event like someone picking the flowers, I said not to because the plants could get hurt. Or when there are ants passing by, then the ants are stamped by my son AN, I say don't do that because it is sinful, the ants don't do anything wrong, so don't bother".

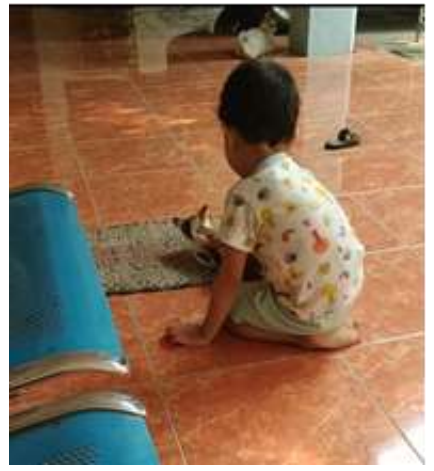

Figure 2 RF's son, KN, playing with cat

Third, only 3 out of 7 parents who develop children's naturalist intelligence at home, the rest entrusted it to school. As the results of an interview with NA, which said that "He can later get naturalist intelligence from school, parents only facilitate".

Fourth, all parents agree that it is important to develop naturalist intelligence early on. As the results of an interview with $\mathrm{KH}$, which said that "Naturalistic intelligence is important so children are aware of the environment as early as possible. The effect of this early development of naturalistic intelligence, children began to get used to maintaining and caring for the surrounding environment. In fact, probably the parents have developed this intelligence indirectly, teaching children to care about the environment, but apparently there is a name of this kind of development, namely naturalistic intelligence, I just knew about it".

Based on the observations, researchers also found that parents who love the environment and nature can actually pass down their naturalistic intelligence to children. Researchers also found that parental background also influences the development of this intelligence, i.e. housewives have more time at home and interact with the children so they have a bigger opportunity to develop the naturalistic intelligence of their children compared to working mothers.

\section{CONCLUSION}

Based on the findings of this research, there are some conclusions and suggestions that can be taken:

1) There is a need for socialization to parents about the importance of developing children's naturalistic intelligence from an early age.

2) There is a need for cooperation between teachers, parents and the government in developing children's naturalistic intelligence from an early age.

3) Further research is needed on children's naturalistic intelligence using different methods and approaches.

\section{REFERENCES}

Ariwidodo, E. (2014). Relevansi pengetahuan masyarakat tentang Lingkungan dan etika lingkungan dengan partisipasinya dalam pelestarian lingkungan. NUANSA: Jurnal Penelitian Ilmu Sosial dan Keagamaan Islam, 11(1), 1-20.

Armstrong, T. (2013). Kecerdasan multipel di dalam kelas. Jakarta: Indeks.

Gunawan, H. (2012). Pendidikan karakter konsep dan implementasi. Bandung: Alfabeta.

Juniarti, Y. (2015). Peningkatan kecerdasan naturalis melalui metode kunjungan lapangan (Field trip). Jurnal Pendidikan Usia Dini, 9(2), 267 - 284.

Nawawi, H. (2003). Metode penelitian bidang sosial. Yogyakarta: Gajah Mada University Press.

Prasetyo, R., \& Andriani, Y. (2009). Multiply your multiple intelligences. Yogyakarta: Andi.

Rocmah, L. I. (2016) Peningkatan kecerdasan naturalis melalui bermain messy play terhadap anak usia 5-6 tahun. PEDAGOGIA: Jurnal Pendidikan, 5(1), 47-56.

Sujiono, Y. N. (2011). Konsep dasar pendidikan anak usia dini. Jakarta: PT Indeks. 
Suyadi. (2010). Psikologi belajar pendidikan anak usia dini. Yogyakarta: PT Pustaka Insan Madani

Wijanarko, J. (2012). Multiple intelligences anak cerdas. Banten: PT. Happy Holy Kids. 